\title{
ANALISA ESTIMASI PRODUKSI PADI BERDASARKAN FASE TUMBUH DAN MODEL PERAMALAN AUTOREGRESSIVE INTEGRATED MOVING AVERAGE (ARIMA) MENGGUNAKAN CITRA SATELIT LANDSAT 8 (STUDI KASUS: KABUPATEN BOJONEGORO)
}

\author{
Vivi Diannita Sari, Bangun Muljo Sukojo \\ Jurusan Teknik Geomatika, Fakultas Teknik Sipil dan Perencanaan, \\ Institut Teknologi Sepuluh Nopember Kampus ITS Sukolilo, Surabaya, 60111, Indonesia \\ Email : bangunms@gmail.com
}

\begin{abstract}
Abstrak
Kabupaten Bojonegoro sebagai penghasil padi andalan di Provinsi Jawa Timur, memiliki misi mewujudkan mimpi menjadi lumbung pangan nasional. Pada tahun 2012, Bulog Bojonegoro menjadi Bulog untuk subdivisi regional tertinggi di seluruh Indonesia. Melihat potensi tersebut, maka perlu adanya upaya untuk memantau kestabilan produksi pertanian secara berkala.
\end{abstract}

Dengan mengintegrasikan teknologi penginderaan jauh menggunakan citra satelit Landsat 8 untuk mengidentifikasi fase tumbuh dan model peramalan Autoregressive Integrated Moving Average (ARIMA) untuk meramalkan produktivitas padi, diharapkan mampu memberikan solusi dan kemudahan dalam pemantauan secara berulang dan kontinu dengan cakupan wilayah yang luas.

Identifikasi fase tumbuh dilakukan dalam 9 fase. Dari proses regresi linier antara fase tumbuh tanaman padi dengan nilai indeks vegetasi yang digunakan, diperoleh nilai koefisien determinasi $\left(R^{2}\right)$ untuk algoritma NDVI sebesar 0,7229 dan algoritma MSAVI sebesar 0,879. Digunakan nilai reflektan dari gelombang band SWIR2 $(1.57 \mu \mathrm{m}-1.65 \mu \mathrm{m})$ untuk membantu membedakan tiap fase tumbuh dari hasil identifikasi algoritma MSAVI dimana untuk pada fase 3, 4, 5 mempunyai reflektan SWIR2 di atas 0,15, sedangkan fase 7, 8, 9 mempunyai reflektan SWIR2 di bawah 0,15.

Proses peramalan produktivitas padi diperoleh model ARIMA musiman $(1,0,0)^{3}$. Sehingga dapat diketahui Angka Ramalan (ARAM) produktivitas padi untuk subround III tahun 2013 adalah sebesar 66,21 kuintal per hektar. Hasil estimasi tertinggi sebesar 169.595,385 ton untuk fase tillering (panen 15 minggu kedepan) dan sebesar 72.246,878 ton untuk fase seedling (panen 13-14 minggu kedepan). Sehingga dapat dilihat bahwa pada saat penelitian dilakukan, Kabupaten Bojonegoro berada pada musim tanam.

Kata Kunci : ARIMA, Fase Tumbuh Padi, Landsat 8, Produktivitas Padi

\section{PENDAHULUAN}

\section{Latar Belakang}

Padi merupakan tanaman penghasil beras yang banyak dibudidayakan di Indonesia. Manajemen stok beras menjadi perhatian bersama sehingga informasi mengenai stok beras sangat penting untuk mengetahui situasi ketersediaan pangan. Di sisi lain data stok ini sangat dibutuhkan dalam penentuan ketersediaan pangan di suatu wilayah karena bisa menyangkut persoalan kerawanan pangan.

Melihat potensi tersebut, upaya pemantauan kestabilan produksi pertanian secara berkala perlu dilakukan. Teknologi penginderaan jauh mampu memberikan solusi dan kemudahan dalam analisis spasial secara berulang, kontinu, serta meliputi wilayah yang relatif luas. Sehingga pendeteksian dan pemantauan perkembangan tanaman padi dapat dilakukan dengan cepat.

Angka ramalan produksi padi telah dilakukan oleh Badan Pusat Statistik (BPS) dengan menggunakan teknik peramalan tidak langsung, yaitu peramalan produksi padi melalui peramalan luas panen dan produktivitas padi. Dari berbagai metode peramalan klasik maupun modern yang berkembang dan masih digunakan untuk meramalkan suatu data deret waktu saat ini, salah satunya adalah ARIMA. Selanjutnya angka ramalan produksi padi sangat diperlukan untuk mendukung kebijakan pemerintah dalam penanganan isu pangan 


\section{METODOLOGI PENELITIAN}

\section{Lokasi Penelitian}

Penelitian ini dilakukan di areal persawahan Kabupaten Bojonegoro, Jawa Timur yang terletak pada koordinat $6^{\circ} 59^{\prime} 0^{\prime \prime}$ LS $-7^{\circ} 37^{\prime} 0^{\prime \prime}$ LS dan $112^{\circ} 25^{\prime} 0^{\prime \prime}$ BT - $112^{\circ} 9^{\prime} 0^{\prime \prime}$ BT. Berikut merupakan gambar dari lokasi penelitian:

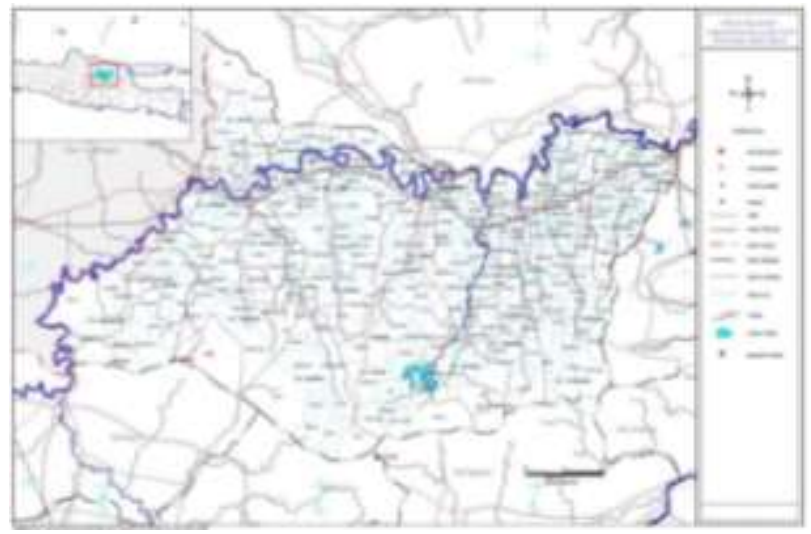

Gambar 1. Lokasi Penelitian Kabupaten Bojonegoro (sumber: Pemerintah Kabupaten Bojonegoro )

\section{Tahap Pengolahan Data}

Adapun proses pengolahan data yang dilakukan tertuang pada diagram alir pengolahan data berikut:

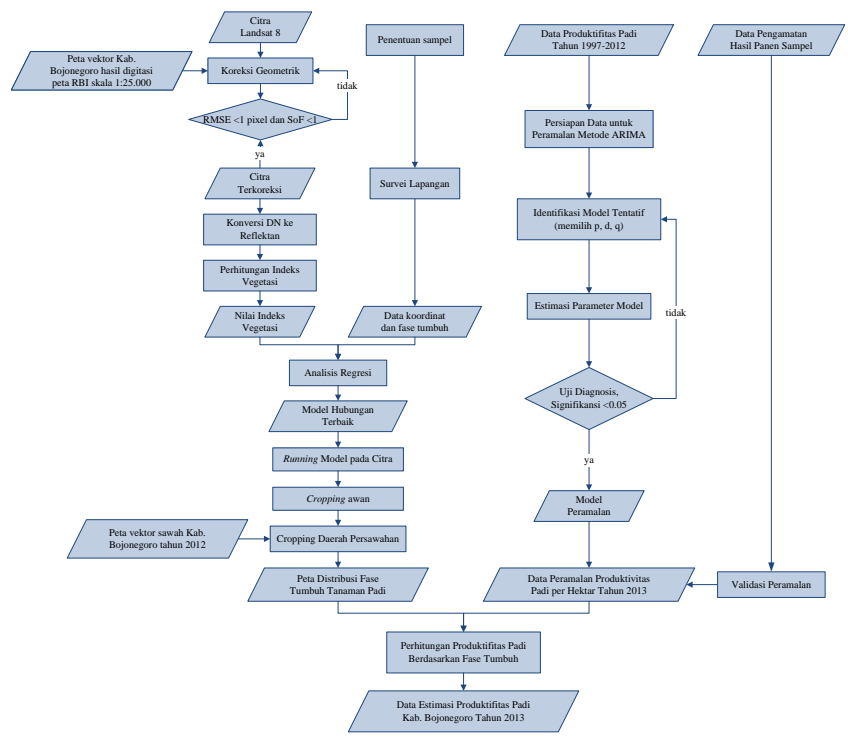

Gambar 2. Diagram Alir Pengolahan Data.

Penjelasan dari diagram alir pengolahan data adalah sebagai berikut :

1. Citra dikoreksi geometrik secara image to image dengan menggunakan pertampalan peta vektor Kabupaten Bojonegoro hasil digitasi peta Rupa Bumi Indonesia (RBI) kabupaten Bojonegoro skala 1:25.000. Ground Control Point (GCP) yang digunakan dipilih pada daerah yang memiliki kenampakan jelas.

2. Setelah didapatkan citra terkoreksi, dilakukan proses konversi Digital Number (DN) ke reflektan.

3. Proses perhitungan indeks vegetasi dilakukan dengan inputan data reflektan yang dihitung berdasarkan algoritma dari setiap indeks vegetasi. Adapun indeks vegetasi yang dihitung adalah NDVI dan MSAVI

4. Sampel berupa luasan sawah ukuran lebih dari sama dengan 30×30 meter dengan fase tumbuh yang homogen sebanyak 9 macam fase.

5. Survei lapangan dilakukan dengan rentang 3 hari sebelum maupun sesudah tanggal perekaman data citra satelit. Hal ini untuk menghindari cepatnya perubahan pertumbuhan tanaman padi. Data yang diambil meliputi koordinat fase tumbuh dan foto keadaan sampel di lapangan.

6. Kemudian dari data fase tumbuh dan nilai Indeks Vegetasi dilakukan proses regresi menggunakan metode regresi linier dan non-linier sesuai dengan transformasi bentuk hubungannya.

7. Dari hasil hubungan setiap indeks vegetasi dan fase tumbuh, dipilih model terbaik dengan memperhatikan nilai koefisien determinasi terbesar dan RMSE terkecil.

8. Hasil model terbaik yang diperoleh kemudian dijalankan pada citra. Setelah itu, dilakukan pemotongan (cropping) awan dan pemotongan citra menggunakan peta vektor daerah persawahan Kabupaten Bojonegoro tahun 2012 untuk mendapatkan peta persebaran fase tumbuh tanaman padi.

9. Sedangkan pada pengolahan data produktivitas padi, digunakan metode ARIMA untuk pembentukan model peramalan time series. Data yang digunakan adalah data subround produktivitas padi tahun 1997-2013. Dari data yang ada, data dipilih dengan distasionerkan untuk dapat dilakukan identifikasi. 
10. Tahap berikutnya dari identifikasi adalah menentukan model ARIMA tentatif. Hal ini dilakukan dengan menganalisis perilaku pola dari ACF dan PACF. Dalam proses ini dipilih $p$ yang merupakan orde/derajat autoregressive (AR), $d$ merupakan orde/derajat differencing (pembedaan), dan q merupakan orde/derajat moving average (MA).

11. Setelah model tentatif ditentukan, parameter model tersebut harus diestimasikan. Selain itu, residual mean kuadrat galat yang merupakan estimasi varian galat $t$ (waktu) juga dihitung.

12. Uji diagnosis dilakukan dengan sistem trials and errors, dimana nilai MSE yang dihasilkan dari berbagai macam kombinasi model ARIMA dapat diperoleh, kemudian model ARIMA yang menghasilkan nilai MSE terkecil dipilih, yang kemudian model ARIMA tersebut dapat digunakan hasil peramalannya untuk memprediksi produktivitas padi subround ke-3 tahun 2013.

13. Begitu didapat model yang memadai, ramalan satu atau bahkan beberapa periode depan dapat dikerjakan.

14. Validasi peramalan dilakukan dengan membandingkan antara hasil peramalan yang diperoleh melalui metode ARIMA dengan data pengamatan hasil panen sampel. Dari sini dapat dilihat perbedaan antara data sekunder dengan data sebenarnya yang diperoleh dari lapangan.

15. Dari data hasil peramalan produktivitas padi per hektarnya, dilakukan perkalian terhadap luasan masing-masing fase tumbuh. Sehingga dapat diperoleh estimasi produksi padi Kabupaten Bojonegoro pada n minggu kedepan.

\section{HASIL DAN PEMBAHASAN}

Koreksi Geometrik dan Perhitungan Srenght of Figure (SoF) pada Citra Landsat 8

Citra satelit Landsat 8 dengan resolusi spasial 30 meter tanggal 26 Desember 2013 dikoreksi secara image to image dengan menggunakan pertampalan peta vektor hasil digitasi peta Rupa Bumi Indonesia (RBI) kabupaten Bojonegoro skala 1:25.000. Sistem proyeksi yang dipakai adalah sistem Universal Transverse Mercator (UTM) zona $49 \mathrm{~S}$, dengan datum World Geodetic System (WGS) 1984.

Dari hasil pelaksanaan koreksi geometrik menggunakan 15 titik GCP, nilai kesalahan Root Mean Square (RMS) adalah 0,333804 piksel. Batas toleransi untuk nilai kesalahan RMS Error adalah 1 piksel [2]. Sehingga dari nilai RMS Error rata-rata yang didapatkan pada koreksi geometrik ini memenuhi syarat tersebut yaitu kurang dari 1 piksel.

Desain jaring titik-titik GCP diatas kemudian dilakukan perhitungan Srenght of Figure (SoF) sebagai berikut: Jumlah Baseline $\quad=34$ Jumlah Titik $=17$

$\mathrm{N}$ Ukuran $\quad=$ Jumlah Baseline $\times 3=102$

$\mathrm{N}$ Parameter $=$ Jumlah Titik $\times 3=51$ Besar SoF $\quad=\frac{\operatorname{Trace}\left(\left(A^{T} A\right)^{-1}\right)}{u}=0.1360$

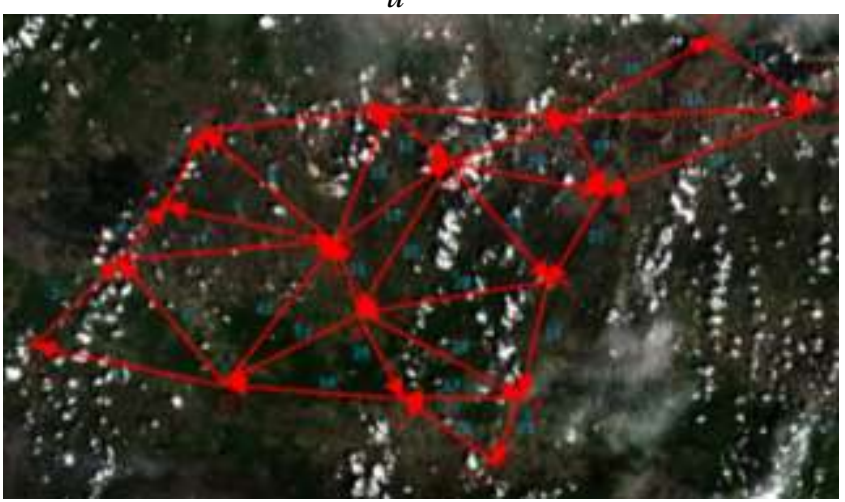

Gambar 3. Sebaran titik GCP dan desain jaring

Nilai SoF yang dihasilkan jaring diatas telah masuk toleransi yang disyaratkan yaitu kurang dari 1, sehingga desain jaring SoF dianggap kuat.

\section{Konversi Digital Number ke Reflektan}

Proses konversi DN ke reflektan dibutuhkan sebagai nilai inputan pada rumusan algoritma indeks vegetasi. Sehingga untuk melakukan proses ini digunakan perhitungan yang melibatkan metadata citra. Adapun rumus konversi DN ke reflektan adalah sebagai berikut :

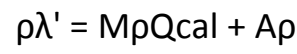

dimana:

$\rho \lambda^{\prime}=$ Nilai reflektan, tanpa koreksi sudut matahari

$\mathrm{M} \rho$ = Faktor multiplicative rescaling setiap band dari metadata (REFLECTANCE_MULT_BAND_x, dimana $x$ adalah nomer band) 

$A \rho=$ Faktor additive rescaling setiap band dari metadata (REFLECTANCE_ADD_BAND_x, dimana $x$ adalah nomer band)
Qcal $=$ Nilai Digital Number band

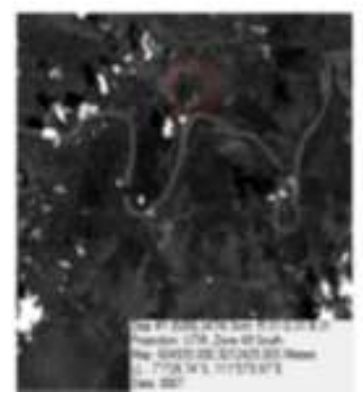

(a)

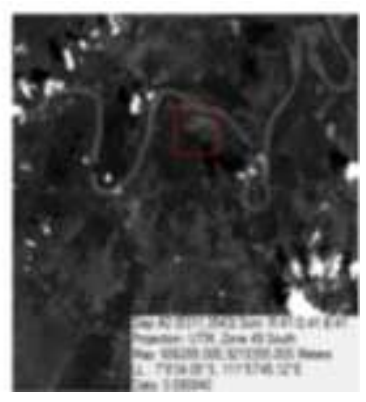

(b)
Gambar 4. (a) Citra sebelum dikonversi, terlihat masih dalam nilai Nigital Number (b) Citra setelah dikonversi, telah berubah dalam nilai reflektan

\section{Persebaran Sampel Setiap Fase Tumbuh}

Pada penelitian ini, sampel diambil secara acak pada beberapa kecamatan di Kabupaten Bojonegoro sebanyak 28 sampel dengan kondisi fase pertumbuhan padi steam elongation hingga mature grain. Pengambilan sampel dilakukan pada tanggal 20-22 Desember 2013. Dari 28 titik koordinat sampel yang diambil, 4 titik sampel diantaranya tidak dapat digunakan. Karena keempat titik tersebut, tertutup awan maupun bayangan awan pada citra. Adapun persebaran sampel fase tumbuh yang diambil adalah sebagai berikut:

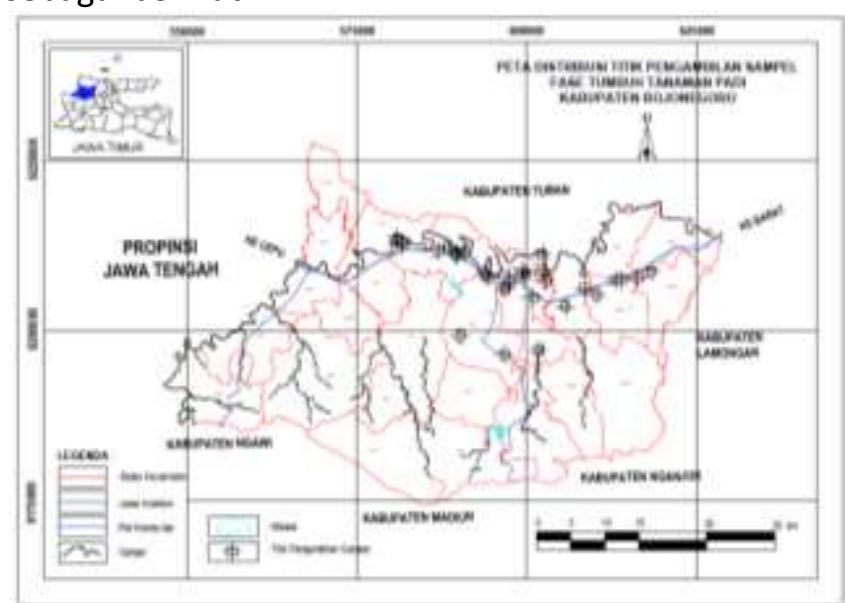

Gambar 5. Distribusi titik pengambilan sampel fase tumbuh tanaman padi kabupaten Bojonegoro

\section{Hasil Analisis Regresi}

Penelitian ini mencoba menggunakan indeks vegetasi yang sudah ada yaitu NDVI dan MSAVI.

$$
N D V I=\frac{N I R-R E D}{N I R+R E D}
$$

MSAVI

$$
=\frac{2 N I R+1-\sqrt{(2 N I R+1)^{2}-8(N I R-R E D)}}{2}
$$

dimana:

$N I R=$ nilai reflektan band spektral infra merah dekat $R E D=$ nilai reflektan band spektral merah

Dari hasil ground truth dan sampel koordinat fase tumbuh tanaman padi, didapatkan nilai indeks vegetasi untuk masing-masing titik sampel fase tumbuh. Kemudian dilakukan proses regresi linier antara fase tumbuh dan nilai indeks vegetasinya, dengan hasil sebagai berikut:

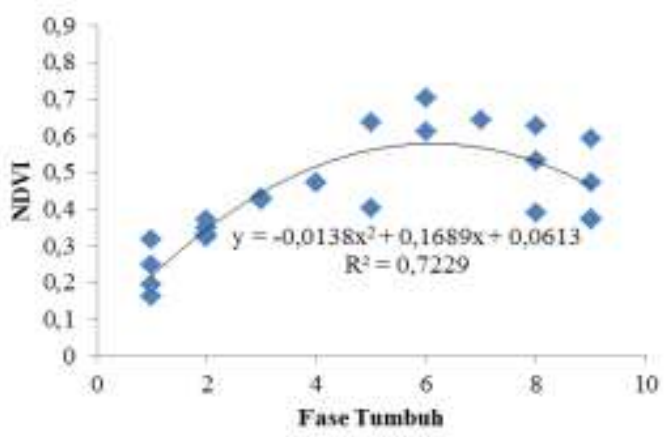

Gambar 6. Kurva hasil regresi antara fase tumbuh dan nilai indeks vegetasi NDVI

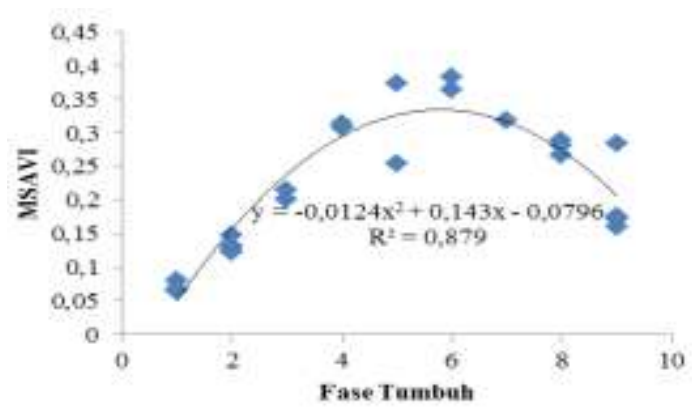

Gambar 7. Kurva hasil regresi antara fase tumbuh dan nilai indeks vegetasi MSAVI

Didapatkan nilai koefisien determinasi NDVI $(0,7229)$ mempunyai nilai koefisien determinasi di bawah MSAVI (0,879). Hal ini karena NDVI lebih sensitif terhadap klorofil, sehingga klorofil dapat membaurkan faktor kerapatan daun. Karena pada prinsipnya nilai NDVI berdasar pada kontras antara absorpsi maksimum klorofil pada panjang gelombang merah dan reflektansi maksimum pada infrared yang disebabkan oleh struktur sel daun. 
NDVI berkorelasi dengan indeks luasan daun atau Leaf Area Index (LAI), akan tetapi NDVI memiliki batasan meliputi tingkat kejenuhan di bawah tutupan kanopi dan sensitif terhadap kondisi atmosfer dan tutupan tanah. MSAVI cukup baik digunakan untuk estimasi kerapatan daun, namun nilai MSAVI ini masih sensitif terhadap pigmen klorofil.

\section{Analisa Model Hubungan Terbaik}

MSAVI dapat dikatakan cukup efektif untuk mendekati fase tumbuh tanaman padi dimana sangat erat hubungannya untuk estimasi kerapatan daun. Hal ini karena pada indeks vegetasi MSAVI nilai efek background dari tanah sudah diminimalisir sehingga reflektansi struktur sel kanopi daun akan lebih baik.

Dalam penelitian Kang, setelah dilakukan analisa dan dibandingkan dengan algoritma lainnya seperti NDVI, SAVI dan PVI, didapatkan algoritma MSAVI tidak hanya dapat meningkatkan sinyal tumbuhan, akan tetapi juga sangat meminimalisir efek tutupan tanah.

Namun pada identifikasi menggunakan MSAVI ini memiliki kesamaan nilai antara fase 3, 4, 5 dan 7, 8, 9 yang dapat terlihat dari kurva yang berbentuk hubungan kuadratik. Untuk itu dimanfaatkan reflektan dari gelombang SWIR2 $(1,57 \mu \mathrm{m}-1,65 \mu \mathrm{m})$ yang terletak pada band 6 di Landsat 8. Gelombang SWIR2 digunakan untuk identifikasi foliage atau daun-daunan.

Dari grafik (Gambar 8) dapat dilihat bahwa nilai reflektan gelombang SWIR2 terhadap tanaman padi akan semakin meningkat seiring dengan pertumbuhan tanaman padi hingga fase tumbuh ke-4 (panicle). Hal ini disebabkan kelembaban tumbuhan masih tinggi dengan daun hijau yang makin lebat dan kelembaban tanah (kandungan air) yang tinggi. Akan tetapi pada fase ke-5 (heading) nilai reflektan mulai menurun, karena kelembaban tanaman padi mulai berkurang akibat mulai keluarnya malai. Begitu juga dengan kelembaban tanah, dimana semakin tua usia padi, kebutuhan airnya semakin berkurang. Namun nilai reflektan SWIR2 terlihat lebih stabil pada fase ini yaitu pada kisaran nilai di bawah 0,15.

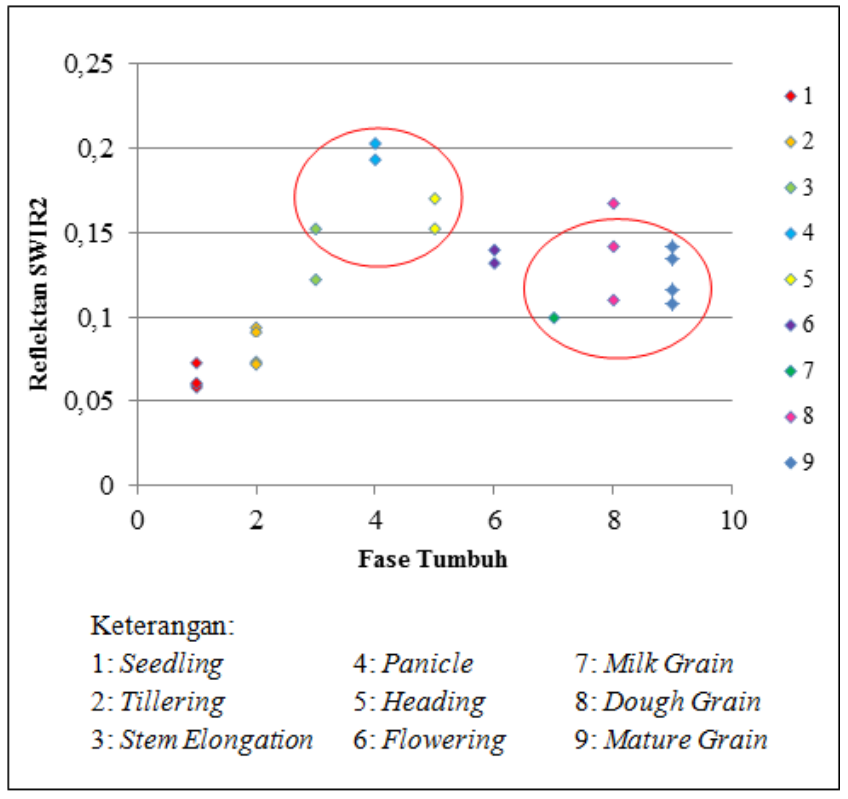

Gambar 8. Grafik hubungan fase tumbuh dan reflektan band SWIR2

Terlihat dari grafik bahwa untuk fase $3,4,5$ mempunyai reflektan di atas 0,15 sedangkan fase 7 , 8, 9 mempunyai reflektan di bawah 0,15.

Pada penelitian yang dilakukan Xiao, dkk [10], digunakan gelombang SWIR $(1,628 \mu \mathrm{m}-1,652 \mu \mathrm{m})$ pada citra satelit MODIS pada algoritma LSWI untuk meningkatkan kelembaban tanah selama periode penggenangan dan penanaman padi. Namun pada penggunaannya, gelombang tersebut dipadukan dengan gelombang NIR $(0,841 \mu \mathrm{m}-0,875 \mu \mathrm{m})$ untuk mendapatkan selisih antara reflektan maksimum gelombang NIR terhadap absorbsi maksimum gelombang SWIR-nya.

\section{Peta Distribusi Fase Tumbuh Tanaman Padi}

Berdasarkan hasil running model hubungan terbaik yaitu MSAVI citra Landsat 8, maka dibuatlah peta distribusi fase pertumbuhan tanaman padi Kabupaten Bojonegoro bulan Desember 2013. Peta ini telah di tampalkan dengan peta vektor area persawahan Kabupaten Bojonegoro tahun 2012 guna menghilangkan daerah yang bukan sawah. Selain itu, juga telah dilakukan proses cloud masking untuk menghilangkan awan.

Untuk mendapatkan luasan area tiap fase tumbuh, digunakan proses Raster to Polygon untuk merubah format asli citra yaitu raster menjadi vektor, dalam hal ini berupa luasan (polygon). Dengan begitu, 
luasan tiap fase tumbuh dapat dihitung dan didapatkan sebagai berikut:

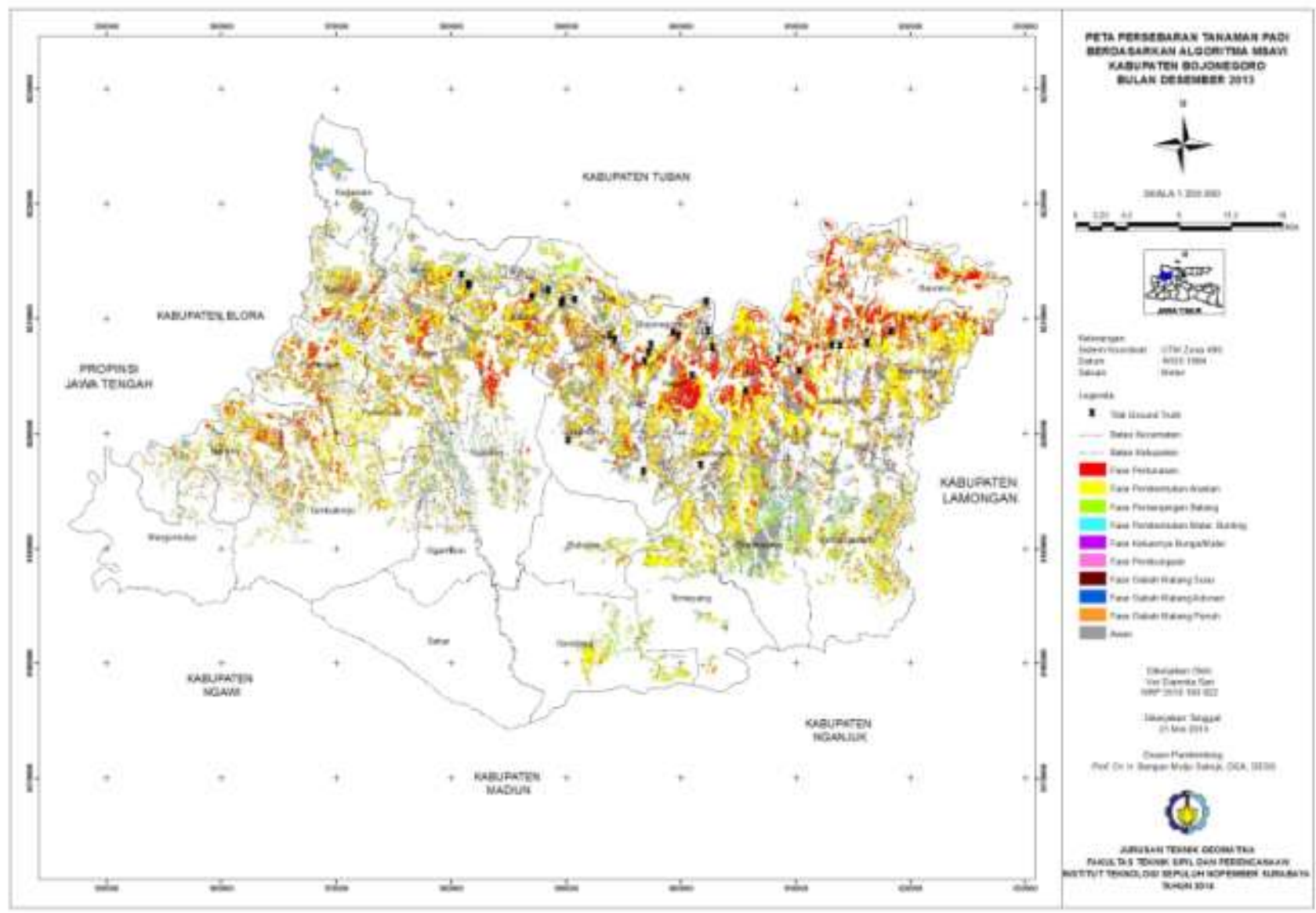

Gambar 9. Peta distribusi fase tumbuh tanaman padi kabupaten Bojonegoro bulan Desember 2013

Tabel 1. Jumlah Luasan Masing-masing Fase Tumbuh Hasil Klasifikasi

\begin{tabular}{ccc}
\hline No. & Fase Tumbuh & Luasan $(\mathrm{Ha})$ \\
\hline 1. & Seedling & $10.912,14$ \\
2. & Tillering & $25.615,62$ \\
3. & Stem elongation & $5.259,06$ \\
4. & Panicle & $2.399,49$ \\
5. & Heading & $1.341,54$ \\
6. & Flowering & 235,53 \\
7. & Milk grain & $1.901,52$ \\
8. & Dough grain & $3.415,50$ \\
9. & Mature grain & $7.727,04$ \\
& Jumlah Luas Panen: & $\mathbf{5 8 . 8 0 7 , 4 4}$ \\
\hline
\end{tabular}

\section{Hasil Peramalan Produktivitas Tanaman Padi}

Gambar 10 menunjukkan time series data insample deret input yaitu produktivitas tanaman padi sawah Kabupaten Bojonegoro tahun 19972013 berpola musiman dengan periode tiga observasi. Hal ini dikarenakan dalam satu tahun terdapat 3 periode subround, yaitu periode Januari-April, Mei-Agustus, dan SeptemberDesember.
Box-Cox plot deret input menunjukkan nilai lambda $(\lambda)=1,0$ dan estimate 0,89 . Nilai $\lambda=1,0$ menunjukkan bahwa data telah stasioner terhadap varian. Apabila dilihat dari time series plot deret input, angka produktifias berada di sekitar mean.

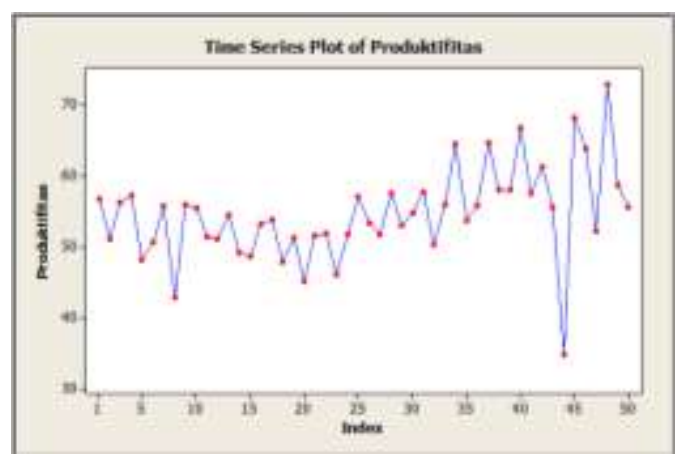

Gambar 10. Time series plot deret input 


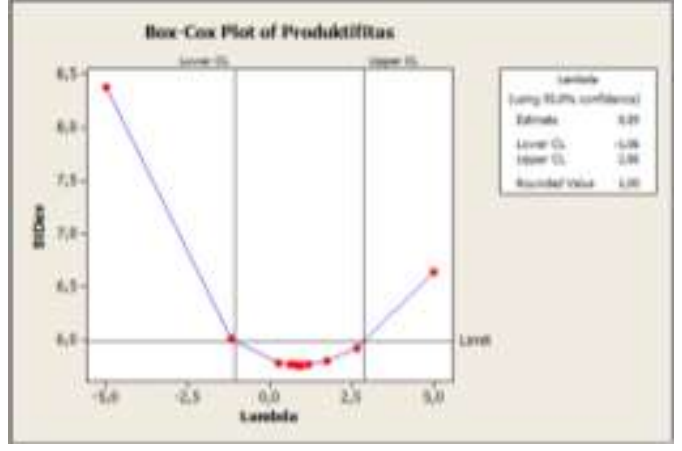

Gambar 11. Box-Cox plot deret input

Identifikasi model Autocorrelation Function (ACF) dan Partial Autocorrelation Function (PACF) menunjukkan bahwa pada ACF plot dapat dilihat bahwa data juga telah stasioner terhadap mean karena ACF berpola turun cepat (dies down) tiap 3 lag yaitu pada lag ke 3, 6, 9, 12 dan 15. Sedangkan PACF plot menunjukkan pola terpotong pada lag 3. Oleh karena itu, dapat diduga model yang sesuai adalah ARIMA musiman $(1,0,0)^{3}$.

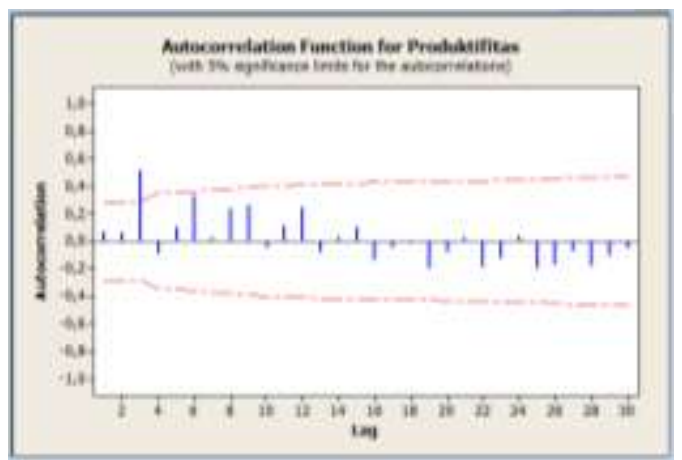

Gambar 11. ACF Plot Produktivitas padi

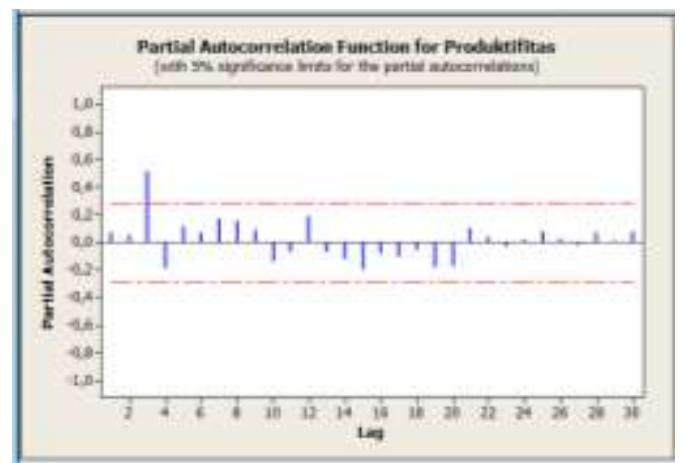

Gambar 13. PACF Plot Produktivitas padi

Sebagai estimasi parameter model digunakan hipotesis sebagai berikut:

$\mathrm{HO}: \Phi=0$

$\mathrm{H} 1: \Phi \neq 0$

Taraf signifikan: $\alpha=0,05$
Statistik Uji :

Tabel 2. Statistik Uji Parameter Model

\begin{tabular}{ccccc}
\hline Tipe & Koefisien & $\begin{array}{c}\text { Standard Error } \\
\text { Koefisien }\end{array}$ & T-Hitung & P-Value \\
\hline AR (1) & 0,6244 & 0,1305 & 4,78 & 0,000 \\
\hline
\end{tabular}

Dari model ARIMA $(1,0,0)^{3}$ menghasilkan $P$-value 0,000 kurang dari taraf signifikan 0,05, maka model signifikan dan $\mathrm{HO}$ ditolak. Akan tetapi, apabila dilakukan cek diagnosa untuk mengevaluasi apakah model ARIMA $(1,0,0)^{3}$ memenuhi asumsi white noise. Dimana white noise adalah suatu proses yang independen dan berdistribusi tertentu dengan mean konstan, biasanya diasumsikan 0 dan variansi konstan [11]. Sehingga digunakan hipotesis:

HO: $\rho=0$ (white noise)

$\mathrm{H} 1: \rho \neq 0$ (tidak white noise)

Taraf signifikan: $\alpha=0,05$

Statistik Uji :

Tabel 3. Statistik Uji model untuk asumsi white noise

\begin{tabular}{lcccc}
\hline \multicolumn{1}{c}{ Lag } & $\mathbf{1 2}$ & $\mathbf{2 4}$ & $\mathbf{3 6}$ & $\mathbf{4 8}$ \\
\hline Chi-Square & 9,5 & 13,9 & 28,5 & 37,1 \\
Degree of Freedom & 10 & 22 & 34 & 46 \\
P-Value & 0,485 & 0,905 & 0,733 & 0,821 \\
\hline
\end{tabular}

Dapat dilihat bahwa nilai $P$-value pada semua lag lebih dari taraf signifikan 0,05 , maka gagal tolak H0. Hal tersebut berarti bahwa model telah memenuhi asumsi white noise.

Dengan demikian persamaan model untuk ARIMA musiman $(1,0,0)^{3}$ adalah sebagai berikut:

$$
\begin{aligned}
\left(1-\Phi_{1} B^{3}\right) Y_{t} & =a_{t} \\
Y_{t}-\Phi_{1} Y_{t-3} & =a_{t} \\
Y_{t} & =\Phi_{1} Y_{t-3} \cdot \varepsilon_{t}
\end{aligned}
$$

Keterangan:

$\Phi=$ koefisien (AR musiman)

$Y_{\mathrm{t}}=$ hasil ramalan periode ke-t (kuintal/ha)

$\varepsilon_{\mathrm{t}}=$ kesalahan ramalan periode ke- $\mathrm{t}$

Maka dari persamaan model di atas, dapat diketahui hasil dari ramalan produktivitas padi $t_{51}$ (subround III tahun 2013) yaitu:

Tabel 4. Hasil Angka Ramalan (ARAM) Produktivitas Tanaman Padi Kabupaten Bojonegoro Subround III Tahun 2013

\begin{tabular}{ccc}
\hline Ramalan & Batas Atas & Batas Bawah \\
\hline 66,2078 & 55,6237 & 76,7919 \\
\hline
\end{tabular}




\section{Produktivitas Tanaman Padi Berdasarkan Validasi Lapangan}

Jumlah produksi padi merupakan hasil perkalian antara luas panen bersih dengan hasil per hektar (produktivitas). Didapatkan nilai Gabah Kering Giling (GKG) dari hasil panen sampel untuk ukuran $2,5 \mathrm{~m} \times 2,5 \mathrm{~m}$ adalah sebesar 3,62 kg. Apabila dengan luas area $6,25 \mathrm{~m}^{2}$ menghasilkan nilai sedemikian, maka dapat diketahui nilai untuk luas area 1 hektar $\left(10.000 \mathrm{~m}^{2}\right)$. Untuk itu dilakukan proses konversi sebagai berikut:

$$
\frac{10.000 \mathrm{~m}^{2}}{6,25 \mathrm{~m}^{2}} \times 3,62 \mathrm{~kg}=5.792 \mathrm{~kg}
$$

Sehingga dapat dihitung selisih antara hasil dari nilai Angka Ramalan (ARAM) dan nilai panen sampel sebesar:

ARAM - N. Panen Sampel $=66,2078-57,92=$

\section{8,2878 kuintal}

Walaupun selisih antara ARAM cukup besar, akan tetapi nilai hasil panen sampel masuk dalam rentang ARAM yaitu antara 55,6237 sampai 76,7919 kuintal.

Dari data yang diperoleh dari Badan Pusat Statistik (BPS) Kabupaten Bojonegoro, ARAM untuk subround III tahun 2013 adalah sebesar 76,70 kuintal. Hal ini hampir sama dengan nilai batas bawah peramalan pada penelitian ini yaitu sebesar 76,80 kuintal. Perbedaan ini dapat disebabkan oleh metode yang digunakan dalam peramalan.

Model ramalan yang digunakan oleh BPS adalah model regresi sederhana, bisa linier atau non linier (logaritma, eksponensial) tergantung pola datanya. Ramalan produksi merupakan perkalian antara ramalan luas panen dengan ramalan produktivitas, dimana luas panen dan produktivitas sudah merupakan resultan dari faktor-faktor yang mempengaruhi produksi. Hasil per hektar yang diperoleh akan mewakili satu subround (4 bulan).

Pada penelitian ini, digunakan citra satelit Landsat 8 untuk meramalkan luas panen. Sedangkan untuk meramalkan produktivitas tanaman padi digunakan model peramalan ARIMA. Model ini digunakan berdasarkan beberapa penelitian sebelumnya yang memperoleh hasil bahwa model ARIMA merupakan model yang baik untuk digunakan peramalan time series [12] [13].

\section{Estimasi Produksi Padi Berdasarkan Fase Tumbuh Hubungannya dengan Indeks Vegetasi MSAVI}

Dari semua uraian di atas diperoleh hasil estimasi produksi beras untuk periode subround III bulan Desember 2013 berikut perkiraan panen untuk $n$ minggu kedepannya dapat dilihat pada Tabel 5.

Tabel 5. Perkiraan Produksi dan Waktu Panen

\begin{tabular}{clcc}
\hline No. & \multicolumn{1}{c}{ Fase Tumbuh } & $\begin{array}{c}\text { Estimasi } \\
\text { Produksi } \\
\text { Padi (ton) }\end{array}$ & $\begin{array}{c}\text { Perkiraan } \\
\text { Waktu } \\
\text { Panen } \\
\text { (minggu) }\end{array}$ \\
\hline 1. & $\begin{array}{l}\text { Seedling (pertunasan) } \\
\text { Tillering } \\
\text { (pembentukan }\end{array}$ & $72.246,878$ & 15 \\
2. & $169.595,385$ & $13-14$ \\
anakan) & $\begin{array}{l}\text { Stem elongation } \\
\text { (pemanjangan batang) }\end{array}$ & $34.819,079$ & $12-13$ \\
4. $\quad \begin{array}{l}\text { Panicle (pembentukan } \\
\text { malai sampai bunting) }\end{array}$ & $15.886,495$ & $10-11$ \\
5. $\quad \begin{array}{l}\text { Heading (keluarnya } \\
\text { bunga atau malai) }\end{array}$ & $8.882,041$ & $9-10$ \\
6. $\quad \begin{array}{l}\text { Flowering } \\
\text { (pembungaan) }\end{array}$ & $1.559,392$ & $8-9$ \\
7. $\quad \begin{array}{l}\text { Milk grain (gabah } \\
\text { matang susu) }\end{array}$ & $12.589,546$ & $4-5$ \\
8. $\quad \begin{array}{l}\text { Dough grain (gabah } \\
\text { matang adonan) }\end{array}$ & $22.613,274$ & $3-4$ \\
9. $\quad \begin{array}{l}\text { Mature grain (gabah } \\
\text { matang penuh) }\end{array}$ & $51.159,032$ & $1-2$ \\
\hline
\end{tabular}

Penelitian ini menghasilkan nilai perkiraan produksi padi berdasarkan peramalan luasan panen dari tiap fase tumbuh. Akan tetapi apabila dilihat dari sisi hubungan antara digunakannya indeks vegetasi MSAVI untuk mengetahui perkiraan produktivitas padi, maka akan terdapat korelasi yang berbeda.

Pada fase seedling hingga tillering nilai MSAVI akan rendah begitu juga dengan produktivitas padi yang dihasilkan. Mengingat pada fase ini, sawah masih tergenangi air dan penampakan tanah masih dominan, sehingga reflektan cenderung pada tubuh air yang menyebabkan rendahnya nilai MSAVI, sehingga sawah belum memiliki nilai produktivitas. Sehingga pada fase tersebut, nilai MSAVI tidak dapat digunakan untuk 
menduga produktivitas padi yang akan dihasilkan pada saat panen.

Pada fase stem elongation sampai flowering nilai MSAVI semakin tinggi, sehingga nilai produktivitas padi juga akan semakin tinggi. Sehingga fase tersebut sudah dapat digunakan untuk menduga produktivitas tanaman padi yang dihasilkan pada saat panen. Namun untuk hasil yang lebih baik, digunakan MSAVI pada fase tumbuh milk grain hingga mature grain. Karena pada fase tersebut, butiran padi mulai matang sehingga perkiraan produktivitas semakin baik.

\section{PENUTUP}

\section{Kesimpulan dan Saran}

Dari hasil penelitian di atas, dapat disimpulkan bahwa diperoleh model terbaik untuk mengidentifikasi 9 fase tumbuh tanaman padi menggunakan algoritma MSAVI. Hasil panen sampel untuk perhitungan produktivitas padi, memiliki hasil yang berada dalam rentang hasil peramalan menggunakan ARIMA. Pada saat penelitian dilakukan, Kabupaten Bojonegoro berada pada musim tanam. Hal ini terlihat pada tingginya nilai perkiraan produksi padi dari fase seedling dan tillering.

Pemantauan produktivitas padi merupakan hal yang sangat penting sepanjang waktu secara temporal untuk menilai bagaimana sistem pertanian yang ada berjalan. Penginderaan jauh merupakan teknologi yang sangat ideal digunakan mengingat beberapa kelebihan seperti jangkauan yang luas dan cepat. Sehingga dengan dimanfaatkannya teknologi penginderaan jauh, penelitian ini memiliki keunggulan metode pemantauan daripada metode yang digunakan oleh BPS.

Sebagai saran guna penelitian selanjutnya, untuk perolehan estimasi yang lebih baik, pemilihan citra hendaknya yang bebas atau minim dari tutupan awan. Atau dapat digunakan citra dengan resolusi spasial lebih kecil. Karena hal ini akan sangat berpengaruh terhadap hasil perhitungan. Pengambilan data sampel lapangan sebaiknya dilakukan dengan rentang 3 hari sebelum maupun sesudah tanggal perekaman data citra satelit. Hal ini dilakukan karena pertumbuhan padi yang relatif cepat. Selanjutnya, penelitian ini dapat dikembangkan dengan mempertimbangkan dampak aspek sosial ekonomi dalam hal pengambilan kebijakan terkait ketahanan pangan

\section{DAFTAR PUSTAKA}

Departemen Pertanian RI. 27 Maret 2013. "Diversifikasi Pangan Harus Digenjot". $<$ URL:

http://pphp.deptan.go.id/disp_informa si

/1/1/0/1410/lagi_lagi_soal_stok_beras .html>. Dikunjungi pada tanggal 8 Oktober 2013, jam 16:35.

Fadhillah, N. 2009. "Perbandingan Metode Pemulusan Eksponensial Winter Aditif dan Box-Jenkins (ARIMA) sebagai Metode Peramalan Curah Hujan Di Kulon Progo D.I. Yogyakarta". Skripsi Universitas NegeriYogyakarta.

Haboudane, Driss dkk. (2004), Hyperspectral Vegetation Indices and Novel Algorithm for Predicting Green LAI of Crop Canopie : Modelling and Validation in the Context of Precision Agriculture. Jurnal Remote Sensing and Environment Vol 90 hal 337-352.

Huete, A., dkk. 2002. Overview of the radiometric and biophysical performance of the MODIS vegetation indices. Remote Sensing of Environment, 83, 195-213.

Kang, Chi Hong. 1996. Methods for Collecting Vegetation Information in Loess Plateau. Act a Botanica Sinica Beijing, 38 (1): 40-44.

Maretha, Dedy. 2008. "Peramalan Produksi dan Konsumsi Kedelai Nasional serta Implikasinya terhadap Strategi Pencapaian Swasembada Kedelai Nasional". Skripsi Institut Pertanian Bogor.

Purwadhi, F. H. 2001. Interpretasi Citra Digital. Jakarta: PT Gramedia Widiasarana Indonesia.

Salamah, Mutiah, dkk. 2003. Buku Ajar: Analisis Time Series. Surabaya: FMIPA Lembaga Penelitian ITS 
Sukmono, Abdi. 2013. "Model Estimasi Kandungan Klorofil dan Kerapatan Daun Tanaman Padi dengan Citra Hyperspectral Berbasis Spektral In Situ". Surabaya: Thesis Institut Teknologi Sepuluh Nopember.

USGS. $2013 . \quad<U R L$ : http://Landsat.usgs.gov/band_designa tions__Landsat_satellites.php >. Dikunjungi tanggal 18 Nopember 2013, jam 11:32.

Xiao, X., dkk. 2002. Landscape-scale characterization of cropland in China using Vegetation and Landsat TM images. International Journal of Remote Sensing, 23, 3579- 3594.

Xiao, X., dkk. 2003. Sensitivity of vegetation indices to atmospheric aerosols: Continental-scale observations in Northern Asia. Remote Sensing of Environment, 84, 385- 392.

Xiao, X., dkk. 2005. Mapping paddy rice agriculture in southern China using multi-temporal MODIS images. Remote Sensing of Environment, 95, 480-492. 